\title{
Priabonian, late Eocene chronostratigraphy, depositional environment, and paleosol-trace fossil associations, Pipestone Springs, southwest Montana, USA
}

\author{
Debra L. Hanneman, Donald Lofgren, Stephen T. Hasiotis, and William C. Mcintosh \\ Acta Palaeontologica Polonica 67 (1), 2022: 5-20 doi:https://doi.org/10.4202/app.00901.2021
}

Sanidine ${ }^{40} \mathrm{Ar} /{ }^{39} \mathrm{Ar}$ ages of lapilli tuffs and the mammalian fauna of Pipestone Springs strata provide a high-resolution chronostratigraphy for upper Eocene (Priabonian) rock units in southwestern Montana. Two felsic lapilli tuffs with weighted-mean ${ }^{40} \mathrm{Ar} /{ }^{39} \mathrm{Ar}$ single crystal sanidine ages of $37.50 \pm 0.02 \mathrm{Ma}$ and $36.00 \pm 0.20 \mathrm{Ma}$ both fall within the Priabonian, late Eocene. These tuffs occur within the basal to upper part of the $55 \mathrm{~m}$ of exposed Pipestone Springs strata. The uppermost $15 \mathrm{~m}$ yield a diverse and abundant assemblage of mostly small-bodied middle Chadronian (Priabonian, late Eocene) mammals. The older lapilli tuff is an ashfall tuff, whereas the younger lapilli tuff exhibits minor aeolian reworking. The new ${ }^{40} \mathrm{Ar} /{ }^{39} \mathrm{Ar}$ age constraints significantly increase the age range of Pipestone Springs strata to include uppermost Duchesnean-lowermost Chadronian (Priabonian, upper Eocene) deposits in addition to its well-known middle Chadronian vertebrate assemblage. These new ${ }^{40} \mathrm{Ar} /{ }^{39} \mathrm{Ar}$ ages combined with its mammalian fauna further support Pipestone Springs strata as age-correlative to the Flagstaff Rim section in central Wyoming, and provide a basis for better determining late Eocene mammalian paleogeography and regional paleolandscapes in the United States Rocky Mountain to Great Plains areas. Loessites intercalated with paleosols dominate Pipestone Springs deposits. The recognition of loessites comprising these strata is a new depositional interpretation of Pipestone Springs strata, making these loessites some of the oldest known aeolian Eocene strata in the Great Plains-Rocky Mountains region. Pipestone Springs paleosols developed on lapilli tuffs are vertisols. Alfisols and inceptisols, developed from a parent material of volcanic glass mixed with non-volcanic grains, are the remaining paleosols within the loessite strata. Additionally, a new and important discovery in this project is the recognition that all paleosols are extensively bioturbated, containing trace fossils similar to Rebuffoichnus and newly identified trace fossils resembling Feoichnus, Eatonichnus, Fictovichnus, and Coprinisphaera.

Key words: Trace fossils,Coprinisphaera, Eatonichnus, Feoichnus, Fictovichnus, Rebuffoichnus, continental strata, paleosol, vertisol, alfisol, inceptisol, loessite, Chadronian, Priabonian, Renova Formation, Montana. 
Debra L. Hanneman [whgeol@gmail.com], Whitehall GeoGroup Inc., 107 Whitetail

Road, Whitehall, Montana 59759, USA. Donald Lofgren [dlofgren@webb.org],

Raymond M. Alf Museum of Paleontology, 1175 Base Line Road, Claremont,

California 91711, USA. Stephen T. Hasiotis [hasiotis@ku.edu], Department

of Geology, University of Kansas, 1475 Jayhawk Boulevard, Lawrence,

Kansas 66045, USA. William C. McIntosh [william.mcintosh@nmt.edu], New Mexico Bureau of Mines and Mineral Resources, 801 Leroy Place, Socorro, New Mexico 87801, USA.

This is an open-access article distributed under the terms of the Creative Commons

Attribution License (for details please see creativecommons.org), which permits unrestricted use,

distribution, and reproduction in any medium, provided the original author and source are credited.

FoF Full text $(4,207.0 \mathrm{kB})$ 